\title{
IMPACT OF THE EU FUNDS ON THE DIVERSIFICATION OF ECONOMIC ACTIVITY (OF FARMS) AND THEIR ROLE IN MULTI-FUNCTIONAL DEVELOPMENT OF RURAL AREAS
}

\author{
${ }^{1}$ Nicolaus Copernicus University in Toruń \\ Department of Spatial Planning and Tourism \\ ul. Lwowska 1, 87-100 Toruń \\ mirbicz@umk.pl \\ ${ }^{2}$ DCRL Dolnośląskie Centrum Rozwoju Lokalnego \\ ul. Jedności Narodowej 45b, 50-260 Wrocław \\ biczkowska.marta@gmail.com
}

Mirosław BICZKOWSKIำ Marta BICZKOWSKA²

\begin{abstract}
The focus of the article is on two issues. One of them is related to the process of multi-functional development of rural areas; the other one concerns the impact the European Union funds have on diversification of economic activity in rural areas. The study attempts to assess this impact with regard to diversification of sources of income gained by rural population and, consequently, with regard to multi-functionality of rural areas. The analysis was based on the number of applications processed and funds acquired within the measures under Axis 3 of the Rural Development Programme 2007-2013 which have provided the most substantial support for multi-functional development of rural areas, i.e. 'Diversification into non-agricultural activities' and 'Creation and development of micro-enterprises'.
\end{abstract}

Key words: multi-functional development, non-agricultural activity, RDP, EU funds, rural areas, diversification of agricultural activity.

\section{Introduction}

For many decades the growth of rural areas in Poland was based on the traditional, mono-functional model of management highly reliant on agricultural activities. Nowadays rural areas are subject to an accelerated deagrarization - both in economic and socio-cultural terms - which is associated with a long-term process of reducing the economic function of agriculture. Thus, there is an increasing significance multi-functionality of rural areas and diversification of sources of income in agricultural holdings.

The changes which originated in the 1990s gained momentum during the last decade upon the accession of Poland to the European Community. On the one hand, this necessitated a wider opening of the Polish market to the global competition; on the other hand, it presented chance for the changes to occur sooner due to the funds absorbed from the European Union budget. This also applies to the widely-defined agricultural sec- 
tor which was covered with the Common Agricultural Policy (CAP) whose objectives include: multi-faceted approach to agriculture and rural areas rooted in the strategy of their multi-functional development. This is because the intensification of the entrepreneurship growth in rural areas became one of the major ideas promoted by the European Union. This was reflected in financial instruments specially designed for the farmers intending to diversify sources of their income (Biczkowski 2008; Bułkowska and Chmurzyńska 2007). Such an approach to rural areas and agriculture has changed the global role of farmers: they ceased to be food-producers only and turned into preservers of natural resources and into economic entities dealing with different activities (Spychalski 2005).

What is of particular significance in reaching the CAP objectives is the Rural Development Programme (RDP). The measures implemented within its framework accelerated the transformation of the Polish rural areas. A distinctly new approach to and perception of the role and function of rural areas may be observed - a departure from the traditional forms of business activity and shifting towards multi-functionality. Implementation of the RDP measures provides favourable conditions for diversification of economic activities and for improvement in the employment rate while attracting people to rural areas in search for new career and lifestyle. These measures are supposed to boost economic competitiveness and stimulate entrepreneurship; consequently, they should contribute to a higher employment in non-agricultural sectors in rural areas.

With prevalence of the agricultural function in the majority of agricultural holdings and their poor economic standing the main target set in the process of stimulating rural areas in Poland is to conduct non-agricultural activity. It constitutes an inevitable element of multi-functional development of rural areas (cf. Bański 2003; Biczkowski 2010; Głaz 2010; Kołodziejczyk 2004; Pałka 2004; Wójcik 2004). As such, it is crucially important for non-agricultural activities to be undertaken in those agricultural holdings which qualify for the relevant RDP funds. In principle, the programme is operated to implement the concept of multi-functional agriculture and rural areas in order to improve the economic condition of agricultural holdings and boost competitiveness of the agri-food sector, for example through the creation of non-agricultural sources of income and promotion of employment in non-agricultural sectors in rural areas.

\section{Methodology and outline of the problem}

The article presents the issues related to the stimulation of multi-functional development of rural areas based on availability of EU funds - particularly the funds dedicated for farmers who intend to increase the volume of non-agricultural activity in their agricultural holdings and diversify their sources of income.

Under the financial framework of 2007-2013 (RDP) a special emphasis was placed on Axis 3 - 'Quality of life in rural areas and diversification of the rural economy' including in particular the following two measures:

- Measure 311 - 'Diversification into non-agricultural activities', and

- Measure 312 - 'Creation and development of micro-enterprises'.

The initiatives undertaken under these measures were mostly related to commencement or development of the activities in the following domains: services for agricultural holdings or forestry; services for rural population; wholesale and retail; craft or handicraft; 
construction and assembly work and services; tourist services, including sport, recreation and leisure; transportation services; public utilities services; processing of agricultural produce or forest edible products; product warehousing or storage; accountancy, consultancy or IT services; and the category which was first time ever separately defined among the European support instruments for alternative sources of income in agricultural holdings - energy production from biomass (RDP 2007).

The article analyses how the RDP 2007-2013 measures mentioned above were implemented, mostly focusing on the number of applications processed and the amount of funds gained from the EU. The study was conducted at the level of regions and poviats (whereby only poviats without towns with district rights were accounted for). Moreover, in order to assess the impact of the RDP measures at the level of non-agricultural activity, a preliminary examination of the general condition of non-agricultural activity in rural areas was carried out.

The basic description of the levels, structure and allocation of the RDP funds was created following a quantitative analysis. To generalize the results achieved, the study of the RDP measures has relied on the composite index ${ }^{1}$ calculated from the standardised values of specific elementary indicators ${ }^{2}$.

Another source of information for this paper included the Local Data Bank of the Central Statistical Office with data on the number of business entities entered into the Register of Business Entities [REGON] ${ }^{3}$.

\section{Concept of multi-functional development of rural areas}

The concept of multi-functional development of rural areas has its origins in the European Regulation (EEC) No 268 of 1975 establishing the necessity to develop areas with non-competitive agriculture (Adamowicz 2005). In 1988 the European Commission carried out a situation analysis of rural areas (The future of rural society - report by the Commission of the European Communities, 1988) and noted a decreasing role of agriculture in the provision of employment in rural areas across Europe. However, it was only in 1996 when multi-functionality was endorsed in the official policy of the Commission, which was published in the Cork Declaration (Adamowicz 2005). That was also when the Council of Europe accepted the European Charter for Rural Areas (1996) for implementation, whereby rural areas were perceived not only as a food provider but also as places where values, lifestyles, cultural heritage and social assets were protected. Such approach helped dedicate CAP support instruments not only for the development of agriculture but also for the development of rural areas. That new delineation of the CAP objectives reflected the departure from the sectoral agricultural policy and a shift towards the rural development policy.

\footnotetext{
1 The developed indicators was presented in form of standardised values. The standardisation method consisted in replacing the original value with the result of multiplication of the difference between a feature value and its mean average by the standard deviation value. Owing to that procedure all of the variables were comparable, the average of their statistical distributions equalled zero and their variances and standard deviations were expressed in full unity digits (Racine andRaymond 1977).

2 Indicators adopted for the analysis are given in chapter "Levels of attractiveness and absorption of RDP funds dedicated for diversification of agricultural activity"

3 Data from the register REGON are for illustrative purposes only. They refer to the total number of business entities entered into the register REGON.
} 
With one of the basic approaches to the multi-functionality of rural areas the agriculture is not perceived as the main source of income. As such, it means introduction of non-agricultural activities to rural areas, creation of new forms of employment, reduction of population gaining their income solely from agriculture, and acceleration of rural restructuring (Głaz 2008; Hunek 1990; Skawińska 1994). It also has an immense influence on the changes in the rural functions (Dietl and Gregor 1979; Stola 1982, 1987, 1993).

M. Kłodziński (1995) interprets the multi-functionality as a strategy of rural development relying on the economic diversification of a commune through integration of more and more non-agricultural functions with the rural space. At the same time, he highlights that the multi-functional development of rural areas is not to be identified with creation of new workplaces only. He sees the multi-functionality in a broader sense - as a concept associated with local development, entrepreneurship, and general diversification of growth areas. On the other hand, T. Hunek (1990) narrows the idea of multi-functionality down to diversification of employment of rural dwellers, which - in his opinion - contributes to the growth in economic activity. D. Kołodziejczyk (2002) aptly notes that the slowdown in diversification of economic activity is a negative economic phenomenon. An economy with a diversified and harmonised structure is more resilient to changes in an economic situation and is more adaptable - a characteristic necessary at the time of structural transformations. It provides conditions for further development of innovativeness in enterprises, among local authorities and population. Communes with a diversified and dynamic economy stand a bigger chance of success in strengthening their position in a spatially broader economic system (p. 54). Therefore, diversification of economic activities is one of the key objectives connected with implementation of the principles governing the multi-functional development (Kłodziński 1996, 2001; Stola 1987, 1993; Zarębski 2002). Basically, the multi-functional development would not be possible without an increase in the significance of non-agricultural activity in the rural areas (Kostrowicki 1976; Stola 1987; Bański 2004; Kamińska 2004; Hasiński et al. 2004, Kłodziński 2004, 2006; Kropsz and Kutkowska 2008).

\section{European programmes and their supporting role in multi-functional development}

In the body of literature on the subject matter analysed here a few attempts to define and describe factors determining the multi-functional development of rural areas may be found, the most important of which include (Adamowicz 2004 following: Durand and Huylenbroeck 2003):

- globalisation and liberalisation of economic relations;

- changes in customers' habits, behavioural patterns and preferences;

- technological and biological progress, and diffusion of innovative solutions in agriculture;

- higher attractiveness of the rural areas;

- structural changes in the rural communities;

- changes in agri-business and system of co-relations between economic entities operating in the agri-food market.

Furthermore, there is still one more determinant of the direction and pace of transformations: availability of support within a wide range of external aid funds. The proof 
of how significant role the EU funds have for the growth of entrepreneurship in rural areas is the project 'Growth of entrepreneurship in rural areas - diagnosis, directions of and recommendations for rural development policy'4. One of the project objectives was to formulate recommendations for further measures targeted at the entrepreneurial growth in rural areas in Poland in the financial framework of 2014-2020 ${ }^{5}$. According to the survey results nearly $70 \%$ of all entrepreneurs benefited from the support available under various initiatives associated with the European funds ${ }^{6}$. It is true for the whole period of integration of Poland with the EU structures and the pre-accession period (i.e. since 2000), when beneficiaries had an opportunity to apply for funds under several measures. Among the basic aid programmes, including those with measures directed at the enhancement of non-agricultural activity, the following deserve particular attention: Special Accession Programme for Agriculture and Rural Development (SAPARD), Sectoral Operational Programme 'Restructuring and modernisation of the food sector and rural development 2004-2006' (SOP Agriculture), and Rural Development Programme (RDP) 2007-2013. Each of these programmes and their measures were associated with different objectives in terms of support for diversification of economic activity.

The SAPARD originated as a support instrument dedicated for countries applying for membership in the European Union. In principle, it was intended to facilitate the processes of structural transformations in rural areas in those countries. The objectives indirectly related to multi-functionality were part of Measure 4: 'Diversification of economic activity in rural areas'. It was mostly designed for the development of non-agricultural activity (services, food processing, craft, ecological farming) and for the creation of conditions favourable for growth of tourism in rural areas. Projects could be co-funded under three schemes: 4.1. Creation of additional sources of income in rural areas; 4.2. Creation of new jobs in rural areas; 4.3. Public tourist infrastructure in rural areas.

Within the framework of another programme - SOP Agriculture - the most important support instrument was to be found under Measure 2.4. Its main objective was to support undertaking or developing additional economic activity with the use of the assets available in a particular agricultural holding and region so as to meet market needs, which was to simultaneously foster the growth of multi-functional and economically-sound agricultural holdings (SOP... 2004).

Finally, when it comes to the RDP 2007-2013 - the last of the completed European programmes which included instruments for the support of the multi-functional development of rural areas - its measures implemented under Axis 3, and partly under Axis 4 - under the 'Leader' approach were of unquestionable importance. The results of the analyses presented in the above-mentioned report pointed to the fact that almost all farmers-entrepreneurs were driven to seek support in the RDP as its mechanism was probably more comprehensible to them because they also took advantage of its various measures to run their agricultural activities ${ }^{7}$.

${ }^{4}$ Creation of the concept of systemic support of entrepreneurship in rural areas within the project 'Growth of entrepreneurship in rural areas - diagnosis, directions of and recommendations for rural development policy'. Strategic report, Institute of Geography and Spatial Organization Polish Academy of Sciences (IGSO PAS), Foundation for the Development of Polish Agriculture, Warsaw 12 May 2014.

\footnotetext{
5 Ibidem, p. 4

6 Ibidem, p.21

7 Ibidem, p. 21.
} 


\section{Growth level of non-agricultural economic activity in rural areas}

The last two decades have seen considerable transformations in the economic structure in rural areas. At the onset of 21st century the rural areas had to face significant structural changes. They resulted from an unfavourable economic condition of the rural areas and from the Polish accession to the European Union as well. The consequent opening of the domestic market to the global market players forced farmers to modernise their agricultural holdings to be able to compete effectively with their international rivals, on the one hand; it also led to changes in business profiles of less economically stable agricultural holdings which failed to meet the requirements imposed by the market, on the other hand. All of that stood behind the growing popularity of non-agricultural activities among rural dwellers. The period of 2002-2014 saw an increase in the number of business entities entered into the Register of Business Entities [REGON] and operating in the rural areas in Poland from 1.58 million to 2.28 million (increase by 702 thousand, i.e. $44.4 \%$ ). Simultaneously, the total number of economic entities rose from 3.47 million to 4.12 million (by 651 thousand, i.e. 18.8\%) across Poland. Thus, it is clear that the dynamics of entrepreneurial growth in rural areas was higher that the national average. At the same time, there is no regular pattern of spatial distribution of this phenomenon (Fig.1). The higher dynamics of change in rural areas is reflected by the fact that their share in 2014 equalled as much as 55.4\% although economic entities registered in rural areas accounted for $45.6 \%$ of all business entities in Poland,. The value of the index of business activities per 10 thousand inhabitants rose from 907.5 (in 2002) to 1,070.6 (in 2014). Here, substantial differences in the spatial distribution may be observed. The result was below 800 in two voivodships (Lubelskie and Podkarpackie), while it approximated 1400 in the Mazowieckie Voivodship.

A similar situation can be observed with the use of other assessment parameters, one of them being the economic activity of rural population in terms of natural persons running a business. For every 1,000 rural inhabitants the index rose from 71 to 77 , whereby the results were considerably higher in western Poland (Fig. 2). The said changes were taking place with the steadily decreasing role of agricultural activity. It resulted from the fact that during the period under analysis the number of agricultural holdings fell by 480 thousand, where 386 thousand were small agricultural holdings (below 5 ha). Owners of small, economically unviable farms were forced to close down their agriculture-related business and seek other sources of income. These included sources of both earned income (sole trading in non-agricultural sectors, hired work) and unearned income (e.g. old-age pensions, disability pensions, etc.) (Rudnicki and Biczkowski 2004). 


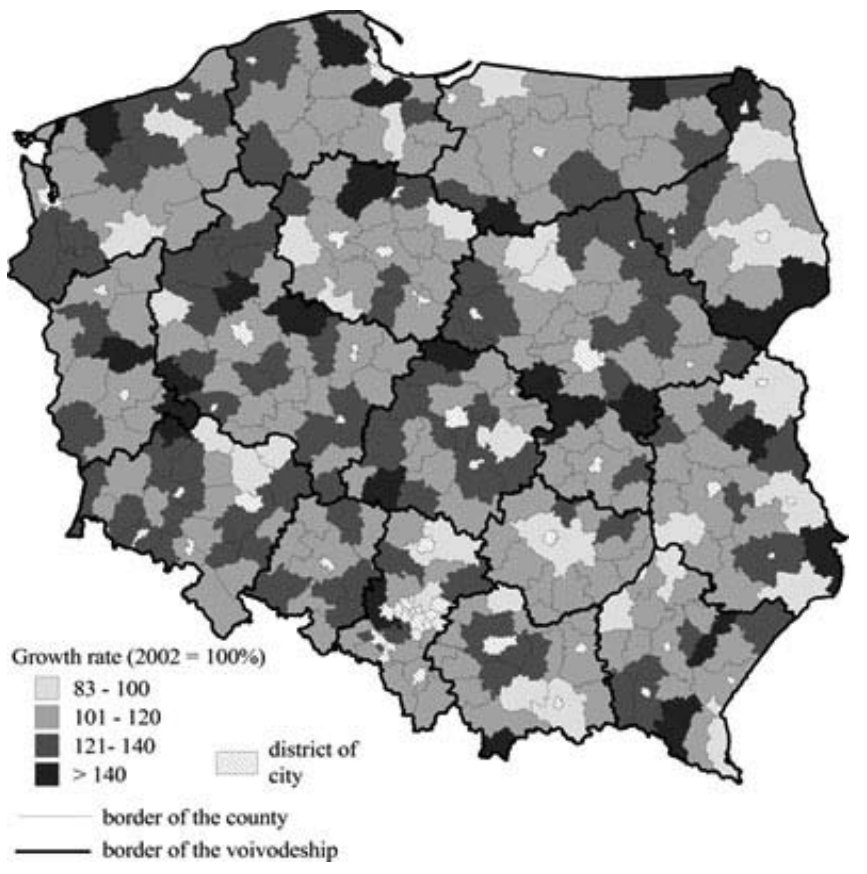

Fig. 1. Dynamics of economic entities in the years 2002-2014 (\%) Source: own study based on REGON register data, LDB CSO Warsaw

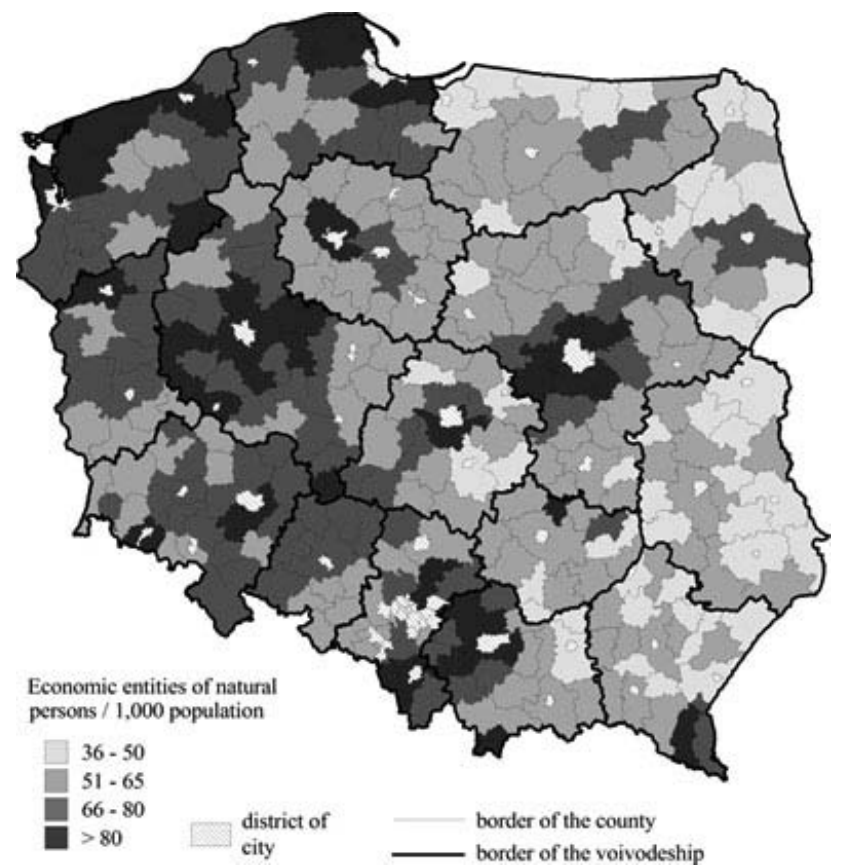

Fig. 2. Natural persons running economic activity per 1,000 persons (2014)

Source: own study based on the REGON register data, LDB CSO Warsaw 
Table 1. Level of entrepreneurship in rural areas - basic data

\begin{tabular}{|c|c|c|c|c|c|c|c|c|}
\hline \multirow[b]{2}{*}{ Voivodeship } & \multicolumn{2}{|c|}{$\begin{array}{l}\text { Natural persons } \\
\text { running economic } \\
\text { activities }\end{array}$} & \multicolumn{2}{|c|}{$\begin{array}{l}\text { Economic entities } \\
\text { entered in the } \\
\text { register REGON }\end{array}$} & \multicolumn{2}{|c|}{ Individual farms } & \multicolumn{2}{|c|}{$\begin{array}{l}\text { Households on } \\
\text { individual farms } \\
\text { having income } \\
\text { from non-agricul- } \\
\text { tural activities }\end{array}$} \\
\hline & 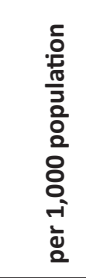 & 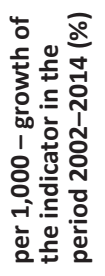 & 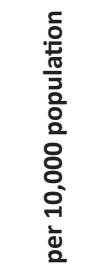 & 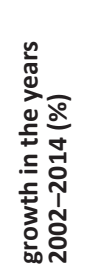 & 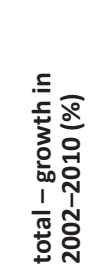 & 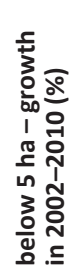 & 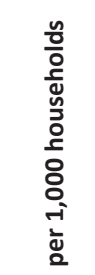 & 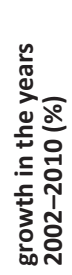 \\
\hline Dolnośląskie & 80.6 & 103.3 & 1207.2 & 118.8 & 79.0 & 75.5 & 157.0 & 190.1 \\
\hline Kujawsko-pomorskie & 68.0 & 93.7 & 919.0 & 103.0 & 77.6 & 66.7 & 168.4 & 261.4 \\
\hline Lubelskie & 60.2 & 111.9 & 799.1 & 117.5 & 90.6 & 92.4 & 148.5 & 393.3 \\
\hline Lubuskie & 76.0 & 103.4 & 1078.9 & 113.7 & 79.3 & 74.0 & 169.6 & 198.1 \\
\hline Łódzkie & 72.0 & 99.7 & 956.7 & 107.4 & 84.8 & 85.0 & 156.4 & 248.1 \\
\hline Małopolskie & 78.1 & 116.2 & 1059.2 & 123.3 & 81.2 & 81.2 & 170.1 & 243.2 \\
\hline Mazowieckie & 93.1 & 115.1 & 1391.3 & 128.8 & 80.3 & 75.8 & 166.0 & 251.2 \\
\hline Opolskie & 71.7 & 118.2 & 999.9 & 124.9 & 61.0 & 53.4 & 194.5 & 230.7 \\
\hline Podkarpackie & 57.1 & 108.6 & 763.5 & 115.9 & 86.5 & 87.5 & 180.6 & 411.5 \\
\hline Podlaskie & 63.7 & 99.1 & 825.0 & 105.4 & 94.7 & 100.0 & 165.9 & 420.4 \\
\hline Pomorskie & 85.9 & 113.5 & 1198.9 & 121.0 & 82.9 & 77.7 & 156.4 & 172.9 \\
\hline Śląskie & 73.1 & 105.8 & 1007.3 & 114.0 & 70.1 & 68.5 & 156.1 & 173.5 \\
\hline Świętokrzyskie & 67.1 & 107.4 & 871.9 & 113.5 & 86.1 & 86.9 & 155.0 & 325.2 \\
\hline Warmińsko-mazurskie & 60.7 & 105.4 & 854.3 & 113.1 & 85.2 & 77.1 & 162.2 & 245.5 \\
\hline Wielkopolskie & 86.6 & 111.7 & 1164.6 & 120.7 & 82.0 & 73.8 & 157.1 & 224.4 \\
\hline Zachodniopomorskie & 94.5 & 103.1 & 1279.0 & 111.2 & 70.3 & 60.3 & 184.3 & 163.1 \\
\hline POLAND & 77.0 & 108.5 & 1070.6 & 118.0 & 82.1 & 79.6 & 163.8 & 260.3 \\
\hline
\end{tabular}

Source: own study based on LDB data, CSO Warsaw

The conclusions drawn from the structure analysis of the sources of income in households of private agricultural holdings are also noteworthy. Conspicuously, there was a substantial rise in the number of households where the incomes from non-agricultural activity prevailed (over $50 \%$ of all incomes). In this case the index values were higher in the western Poland (Fig. 3), although recent years have been characterised by more dynamic changes recorded in poviats located in the eastern Poland (Fig. 4). It means that the process of departing from agricultural activity is gaining pace there. 


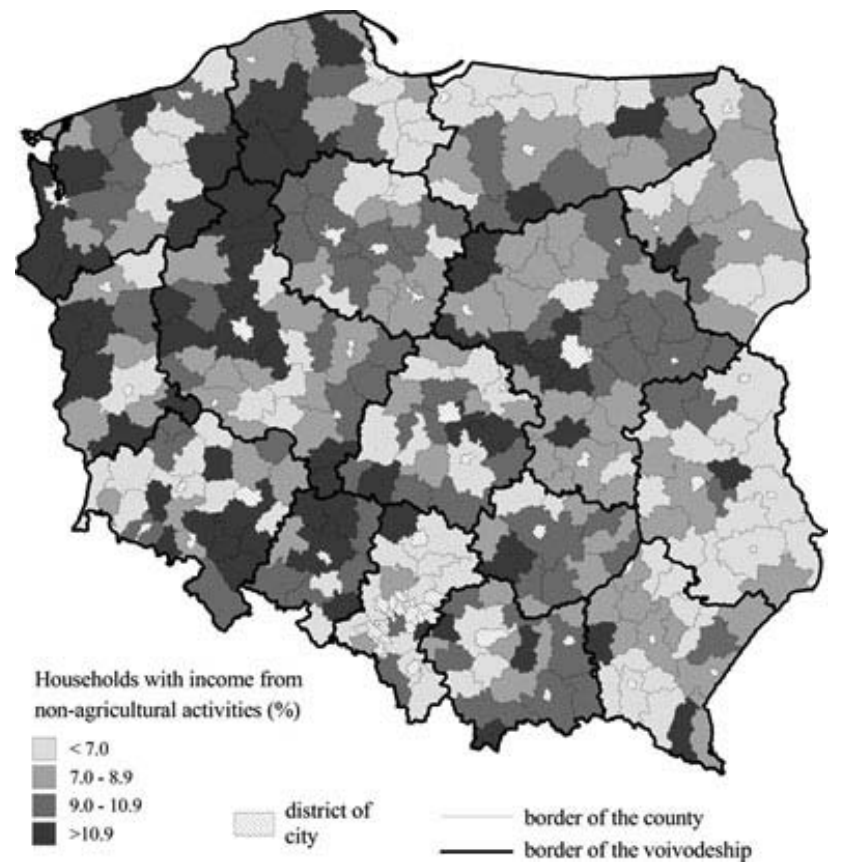

Fig. 3. Individual farm households obtaining income from non-agricultural activities (\%) Source: own study.

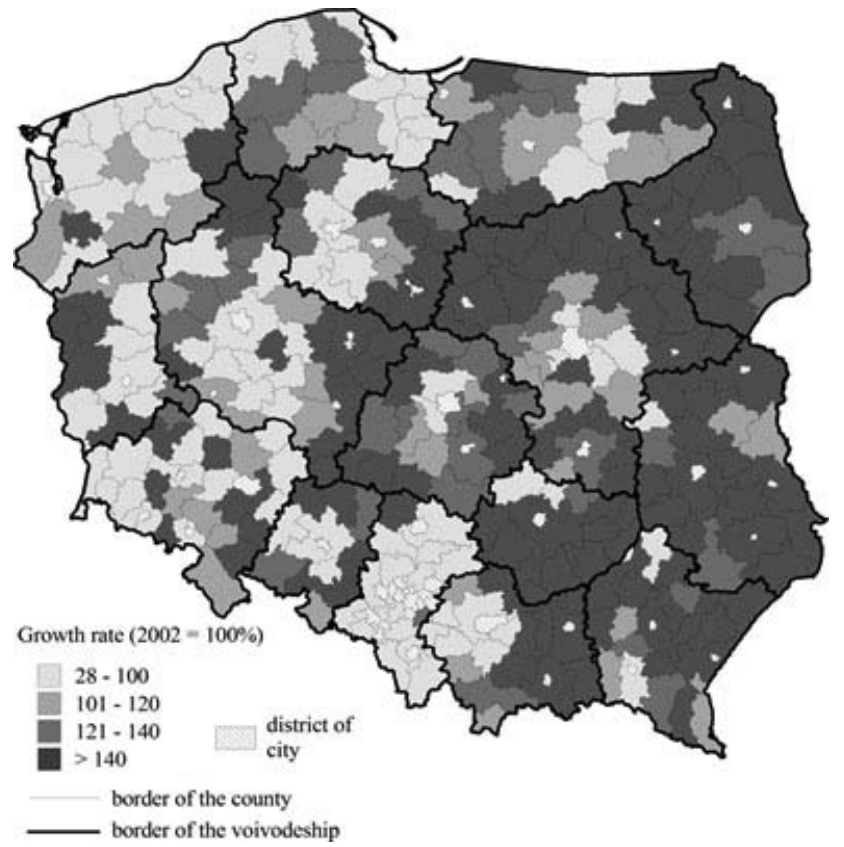

Fig. 4. Dynamics of individual farm households obtaining income from non-agricultural activities in the years 2002-2010 (2002=100)

Source: own study. 


\section{Levels of attractiveness and absorption of RDP funds designed for diversification of agricultural activity}

Overall, there were 24,634 applications processed under the two measures studied. With regard to the spatial pattern, the measures enjoyed quite a different popularity among beneficiaries. The largest number of projects was implemented in the Wielkopolskie Voivodship $(4,284)$ and Mazowieckie Voivodship $(3,214)$, whereas the Lubuskie Voivodship came last (533) in this ranking. With regard to poviats, the record was in the poviat of Kalisz (357), down to 10 applications in the poviats of Mikołów, Grodzisk Mazowiecki and Skarżysko-Kamienna (Fig. 5).

Table 2. Level of activity and absorption of the RDP funds in total

\begin{tabular}{|c|c|c|c|c|c|c|c|c|c|}
\hline \multirow{3}{*}{ Voivodeship } & \multirow{2}{*}{\multicolumn{3}{|c|}{$\begin{array}{l}\text { Number of completed } \\
\text { applications }\end{array}$}} & \multicolumn{6}{|c|}{ Amount of payments (bn PLN) ${ }^{8}$} \\
\hline & & & & \multicolumn{3}{|c|}{ total } & \multicolumn{3}{|c|}{ under the RDP measures } \\
\hline & $\begin{array}{l}\text { ope- } \\
\text { ration } \\
\mathbf{3 1 1}\end{array}$ & $\begin{array}{c}\text { ope- } \\
\text { ration } \\
312\end{array}$ & total & $\begin{array}{c}\text { ope- } \\
\text { ration } \\
311\end{array}$ & $\begin{array}{c}\text { ope- } \\
\text { ration } \\
312\end{array}$ & total & $\begin{array}{c}\text { ope- } \\
\text { ration } \\
311\end{array}$ & $\begin{array}{c}\text { ope- } \\
\text { ration } \\
312\end{array}$ & total \\
\hline Dolnośląskie & 425 & 341 & 766 & 37.6 & 56.8 & 94.3 & 28.2 & 42.6 & 70.8 \\
\hline Kujawsko-pomorskie & 706 & 433 & 1139 & 64.5 & 77.7 & 142.2 & 48.4 & 58.3 & 106.6 \\
\hline Lubelskie & 1368 & 881 & 2249 & 116.8 & 150.1 & 266.9 & 87.6 & 112.6 & 200.2 \\
\hline Lubuskie & 265 & 268 & 533 & 24.5 & 48.9 & 73.4 & 18.4 & 36.7 & 55.1 \\
\hline Łódzkie & 859 & 450 & 1309 & 75.8 & 77.1 & 152.9 & 56.8 & 57.8 & 114.6 \\
\hline Małopolskie & 667 & 1084 & 1751 & 53.1 & 177.9 & 231.0 & 39.8 & 133.4 & 173.3 \\
\hline Mazowieckie & 2142 & 1072 & 3214 & 197.8 & 191.6 & 389.4 & 148.3 & 143.7 & 292.0 \\
\hline Opolskie & 407 & 308 & 715 & 34.8 & 48.3 & 83.1 & 26.1 & 36.2 & 62.3 \\
\hline Podkarpackie & 619 & 1015 & 1634 & 47.5 & 171.7 & 219.3 & 35.6 & 128.8 & 164.4 \\
\hline Podlaskie & 1089 & 434 & 1523 & 99.5 & 75.3 & 174.9 & 74.7 & 56.5 & 131.1 \\
\hline Pomorskie & 468 & 578 & 1046 & 41.5 & 102.9 & 144.4 & 31.2 & 77.2 & 108.3 \\
\hline Śląskie & 441 & 828 & 1269 & 37.2 & 150.4 & 187.6 & 27.9 & 112.8 & 140.7 \\
\hline Świętokrzyskie & 657 & 505 & 1162 & 56.6 & 79.1 & 135.7 & 42.5 & 59.3 & 101.8 \\
\hline Warmińsko-mazurskie & 743 & 521 & 1264 & 66.6 & 99.3 & 165.9 & 50.0 & 74.5 & 124.4 \\
\hline Wielkopolskie & 2953 & 1331 & 4284 & 276.7 & 262.3 & 539.0 & 207.5 & 196.7 & 404.3 \\
\hline Zachodniopomorskie & 389 & 387 & 776 & 35.5 & 67.9 & 103.4 & 26.6 & 50.9 & 77.6 \\
\hline POLAND & 14198 & 10436 & 24634 & 1266.1 & 1837.2 & 3103.4 & 949.6 & 1377.9 & 2327.5 \\
\hline
\end{tabular}

Source: own study based on data of the Agency for Restructuring and Modernisation of Agriculture, Warsaw

Taking into account the differences in the endogenic potential of specific territorial units, the absolute values were juxtaposed with the number of prospective beneficiaries. The point of reference was of two types: agricultural holdings in total and small farms (below 5 ha), as they are a perfect choice for the development of non-agricultural activity due to their negligible (in the most cases) economic power. The analysis included

\footnotetext{
8 In this article American English version is used ( $b n=1,000,000,000=109)$.
} 
also households of those agricultural holdings which drew incomes from non-agricultural activity. For a better presentation of the impact of RDP measures on the diversification of economic activity the number of applications processed was analysed per 1000 economic entities and 1000 natural persons running a business (as of 2014). Table 3 provides the results broken down by regions.

At the level of poviats the spatial pattern of each of the indices calculated is highly diversified as follows:

- according to the number of applications processed per 1000 agricultural holdings of any acreage (on average in Poland: 11.2): from 1.5-1.6 in the poviats of Jasło and Skarżysko-Kamienna to almost 59 in the poviats of Września and Środa Wielkopolska;

- according to the number of applications processed per 1000 small farms, i.e. below 5 ha (on average in Poland: 16.3): from 1.6 in the poviats of Jasło and SkarżyskoKamienna to 154 in the poviat of Kolno (Fig. 6);

- according to the number of applications processed per 1000 households in private agricultural holdings with incomes from non-agricultural economic activity (on average in Poland: 68.3): from 9.4 in the poviat of Grodzisk Mazowiecki and 9.6 in the poviats of Mikołów and Jasło to 556.2 in the poviat of Września (Fig. 7);

- according to the number of applications processed per 1000 natural persons running a business (on average in Poland: 8.3): from below 1.0 in the poviats of Grodzisk Mazowiecki and Mikołów to 95.7 in the poviat of Łomża;

- according to the number of applications processed per 1000 economic entities entered into the Register of Business Entities [REGON] (on average in Poland: 6.0): from below 1.0 in the poviats of Mikołów, Grodzisk Mazowiecki and Chrzanów to 77.3 in the poviat of Łomża.

For the general assessment of beneficiaries' activity concerning submission of applications, the above-mentioned indicators were analysed in total in the form of composite index showing the level of beneficiaries' involvement into diversification of their economic activity. So designed analysis showed that the lowest levels were in the case of the beneficiaries from the northern Poland, particularly from the regions of Wielkopolska and northern Mazowsze. In terms of poviats, low figures were characteristic of the poviats of:

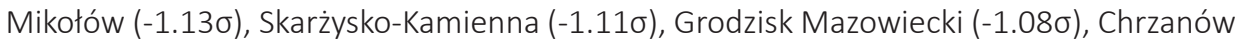
$(-1.08 \sigma)$, Wołomin $(-1.04 \sigma)$, Jasło $(-1.02 \sigma)$, Bieruń $(-1.02 \sigma)$, and Wadowice $(-1.01 \sigma)$. On the other hand, the most intensive entrepreneurial activity was recorded in the povi-

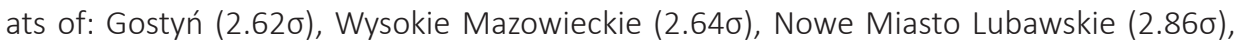

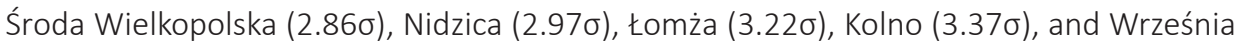

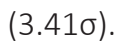

Another parameter determining the impact of the RDP funds dedicated to the nonagricultural activity growth in the rural areas is the amount of payments granted to beneficiaries. Altogether, within the two measures analysed, the implemented ventures were worth PLN 3.10 bn, out of which PLN 2.33 bn came from the RDP funds (75\% of the total value of investment), while the rest was covered by the investors themselves. Definitely, the largest share of European funds was received by the beneficiaries from the Wielkopolskie Voivodship (PLN 404.3 bn, i.e. 17.4\% of all RDP funds; Fig. 8). The lowest support was transferred to beneficiaries from the Lubuskie Voivodship (PLN 55.0 bn) and Opolskie Voivodship (PLN 62.3 bn). When it comes to poviats, the largest amounts 
of payments - over PLN 25 bn - were noted in six units: Kalisz (PLN 32.1 million), Konin (PLN 28.6 million), Rzeszów (PLN 27.8 million), Kielce (PLN 27.2 million), and Lublin (PLN 27.2 million). The lowets amounts - below PLN 1 million - were granted to five poviats of: Mikołów (PLN 403.1 thousand), Grodzisk Mazowiecki (PLN 710.5 thousand), Bieruń (PLN 712.6 thousand), Kamienna Góra (PLN 954.4 thousand), and Polkowice (PLN 970.6 thousand).

Table 3. Basic indicators of the level of activity and absorption of the RDP funds

\begin{tabular}{|c|c|c|c|c|c|c|c|c|c|c|}
\hline \multirow[b]{2}{*}{ Voivodeship } & \multicolumn{5}{|c|}{$\begin{array}{l}\text { Number of completed applications } \\
\text { per } 1,000\end{array}$} & \multicolumn{4}{|c|}{$\begin{array}{l}\text { Funds paid out of the RDP } \\
\text { per } 1 \text { (in PLN) }\end{array}$} & \multirow[b]{2}{*}{ 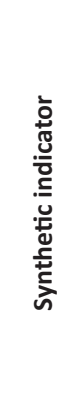 } \\
\hline & 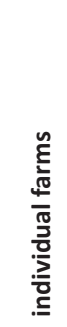 & 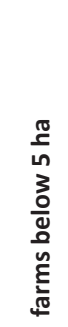 & 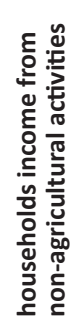 & 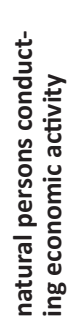 & 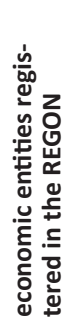 & 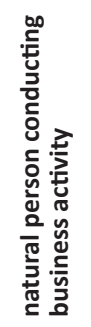 & 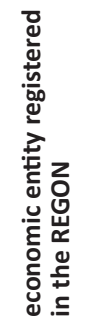 & 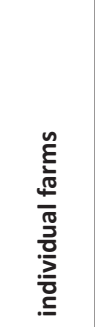 & 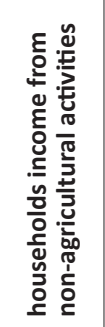 & \\
\hline Dolnośląskie & 7.5 & 10.6 & 47.7 & 3.3 & 2.2 & 402.4 & 268.7 & 927.7 & 4410.8 & -1.04 \\
\hline Kujawsko-pomorskie & 13.5 & 29.3 & 80.0 & 8.0 & 5.9 & 999.9 & 740.2 & 1687.9 & 7490.1 & 0.02 \\
\hline Lubelskie & 8.9 & 13.5 & 59.6 & 17.4 & 13.1 & 2063.4 & 1555.1 & 1051.3 & 5304.8 & 0.08 \\
\hline Lubuskie & 12.9 & 17.6 & 75.6 & 6.9 & 4.8 & 947.1 & 666.8 & 1776.6 & 7807.8 & -0.17 \\
\hline Łódzkie & 7.9 & 13.4 & 50.5 & 7.3 & 5.5 & 847.5 & 638.0 & 922.4 & 4420.3 & -0.73 \\
\hline Małopolskie & 6.3 & 6.9 & 36.8 & 6.7 & 4.9 & 877.9 & 647.5 & 826.6 & 3642.2 & -0.95 \\
\hline Mazowieckie & 12.0 & 22.3 & 72.4 & 6.5 & 4.3 & 784.3 & 524.7 & 1458.4 & 6582.3 & -0.32 \\
\hline Opolskie & 16.3 & 24.7 & 83.2 & 10.0 & 7.1 & 1157.7 & 830.7 & 1891.6 & 7255.6 & 0.12 \\
\hline Podkarpackie & 6.5 & 7.2 & 35.7 & 13.4 & 10.1 & 1802.4 & 1348.8 & 865.7 & 3592.7 & -0.45 \\
\hline Podlaskie & 15.0 & 36.1 & 90.0 & 20.1 & 15.5 & 2302.8 & 1778.0 & 1716.9 & 7753.2 & 0.96 \\
\hline Pomorskie & 18.4 & 33.7 & 117.1 & 5.3 & 3.8 & 730.3 & 523.3 & 2540.3 & 12127.4 & 0.52 \\
\hline Śląskie & 9.2 & 10.4 & 58.8 & 3.8 & 2.7 & 559.4 & 406.1 & 1358.7 & 6521.1 & -0.72 \\
\hline Świętokrzyskie & 8.2 & 10.8 & 52.8 & 13.7 & 10.6 & 1601.6 & 1232.1 & 955.7 & 4621.7 & -0.30 \\
\hline Warmińsko-mazurskie & 19.3 & 36.8 & 118.5 & 14.4 & 10.2 & 1891.8 & 1345.0 & 2532.1 & 11662.3 & 1.18 \\
\hline Wielkopolskie & 27.1 & 51.5 & 172.0 & 14.2 & 10.6 & 1792.0 & 1332.8 & 3411.8 & 16225.8 & 2.02 \\
\hline Zachodniopomorskie & 17.1 & 28.5 & 91.6 & 4.8 & 3.5 & 638.3 & 471.4 & 2275.2 & 9158.9 & 0.07 \\
\hline POLAND & 11.2 & 16.3 & 68.3 & 8.3 & 6.0 & 1048.0 & 753.3 & 1411.8 & 6451.1 & \\
\hline
\end{tabular}

Source: own study based on data of Agency for Restructuring and Modernisation of Agriculture, Warsaw and LDB, CSO Warsaw. 


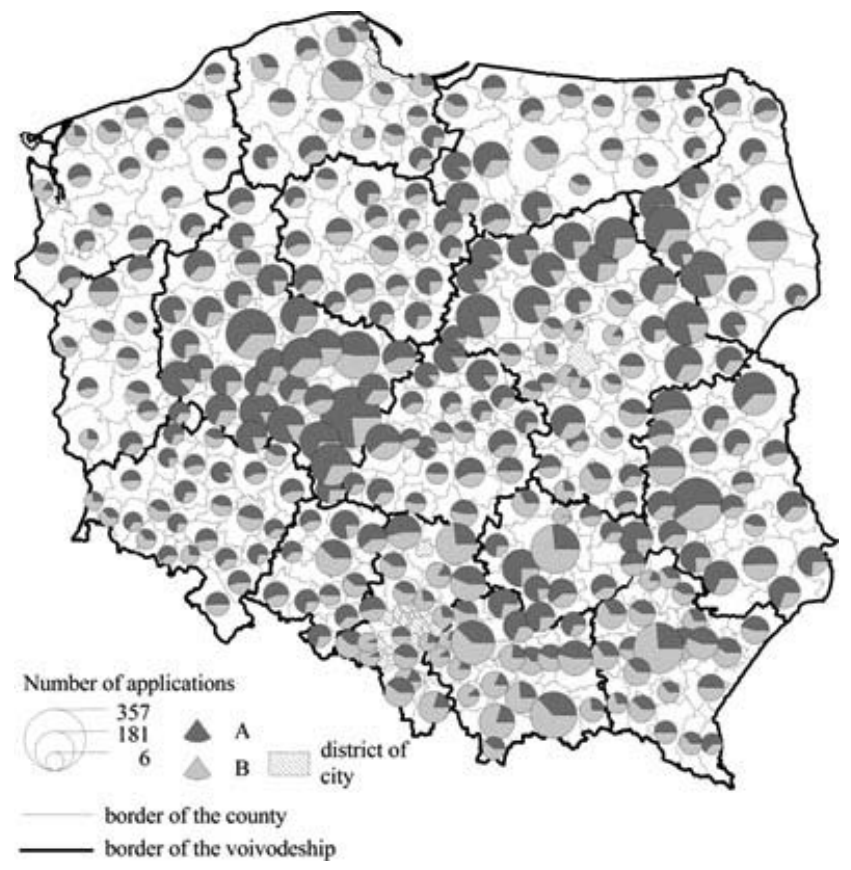

Fig. 5. Total number of implemented applications ( $\mathrm{A}$ - operation 311, B - operation 312) Source: own study.

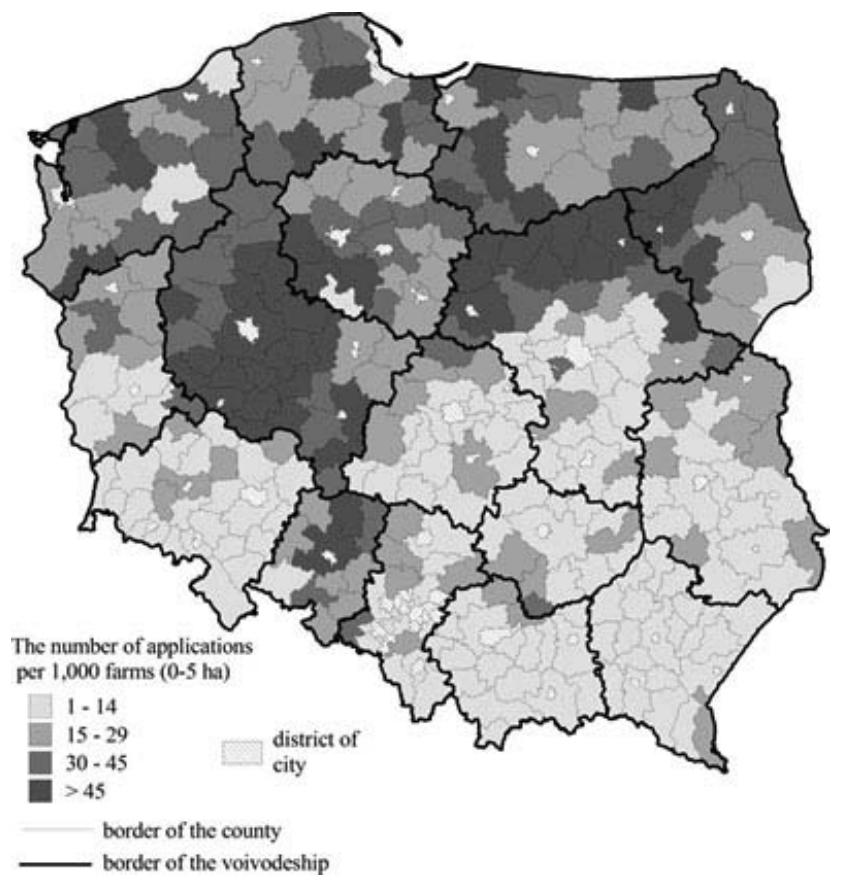

Fig. 6. Number of implemented applications per 1,000 farms below 5 ha Source: own study. 


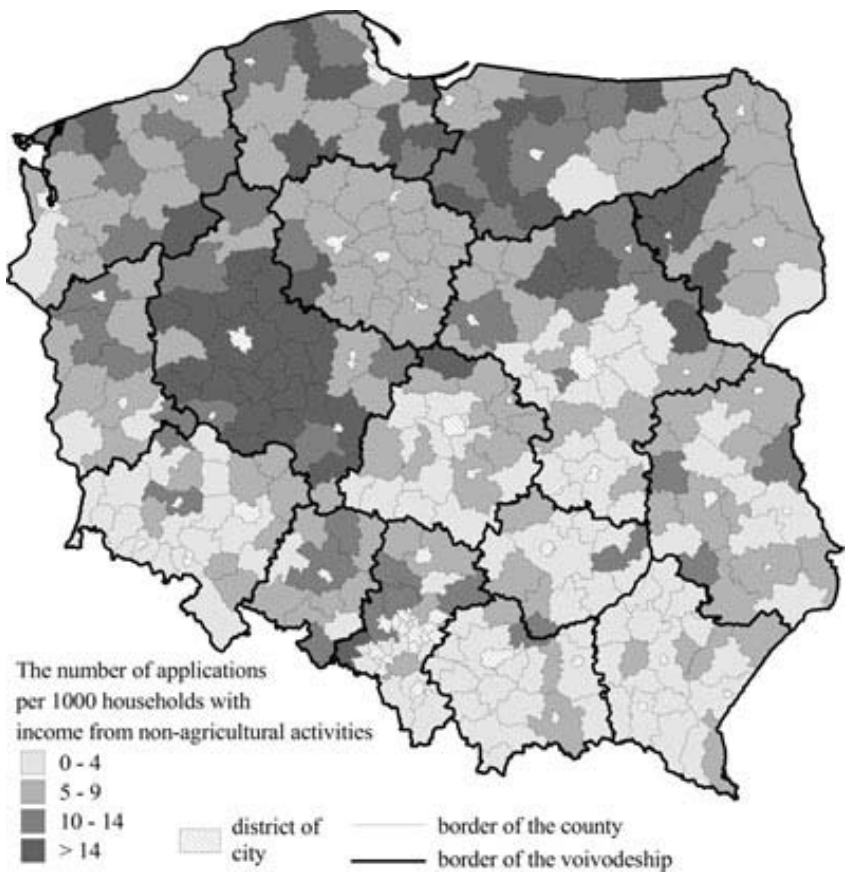

Fig. 7. Number of implemented applications per 1,000 households of individual farms with income from nonagricultural activities Source: own study.

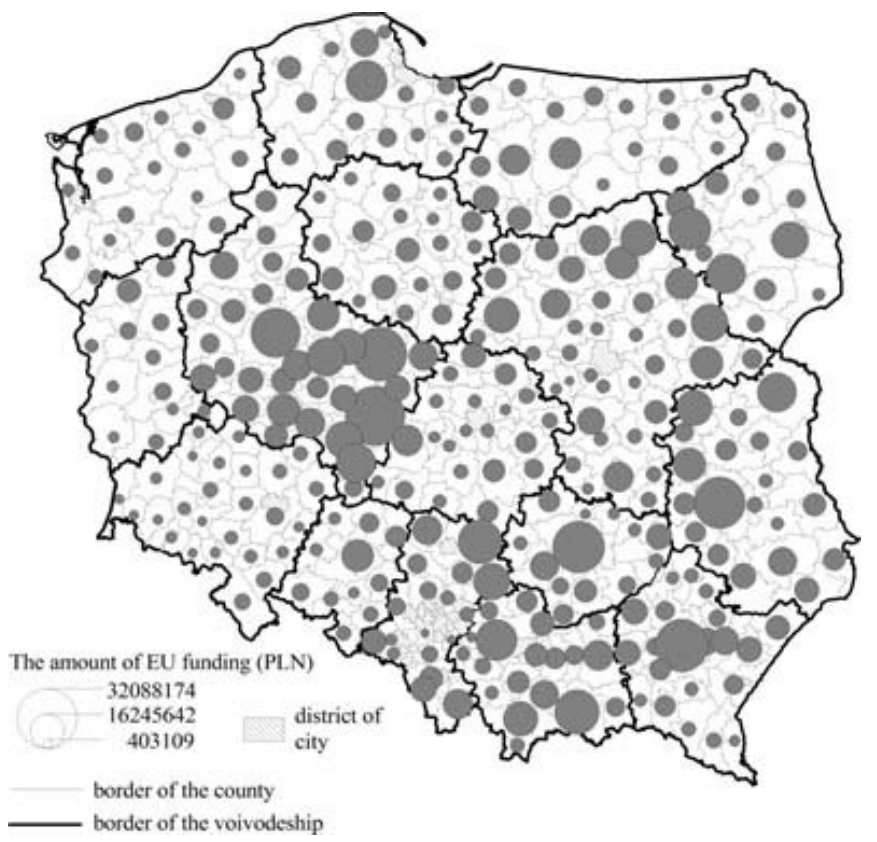

Fig. 8. Amount of absorption under the RDP in total (PLN) Source: own study. 
As was the case with the level of measures' attraction for the beneficiaries, the payments were also subjected to indexation and several indicators were used to account for the number of would-be beneficiaries in each administrative unit with self-government. The amounts paid to the beneficiaries under the RDP measures were calculated for individual poviats according to:

- agricultural holding (in Poland: PLN 1,412 on average): from PLN 116 in the poviat of Mikołów to PLN 5,964 in the poviat of Września;

- household of agricultural holding with incomes from non-agricultural economic activity (in Poland: PLN 6,451 on average): from PLN 647 in the poviat of Mikołów to PLN 56.6 thousand in the poviat of Września (Fig. 9);

- economic entity run by natural persons (in Poland: PLN 1,048 on average): from below PLN 100 in the poviats of Mikołów and Grodzisk Mazowiecki to PLN 8,705 in the poviat of Łomża (Fig. 10);

- economic entity entered into the Register of Business Entities [REGON] (in Poland: PLN 753 on average): from below PLN 60 in the poviats of Mikołów and Grodzisk Mazowiecki to over PLN 5 thousand in the poviats of Kolno and Kalisz and PLN 7 thousand in the poviat of Łomża.

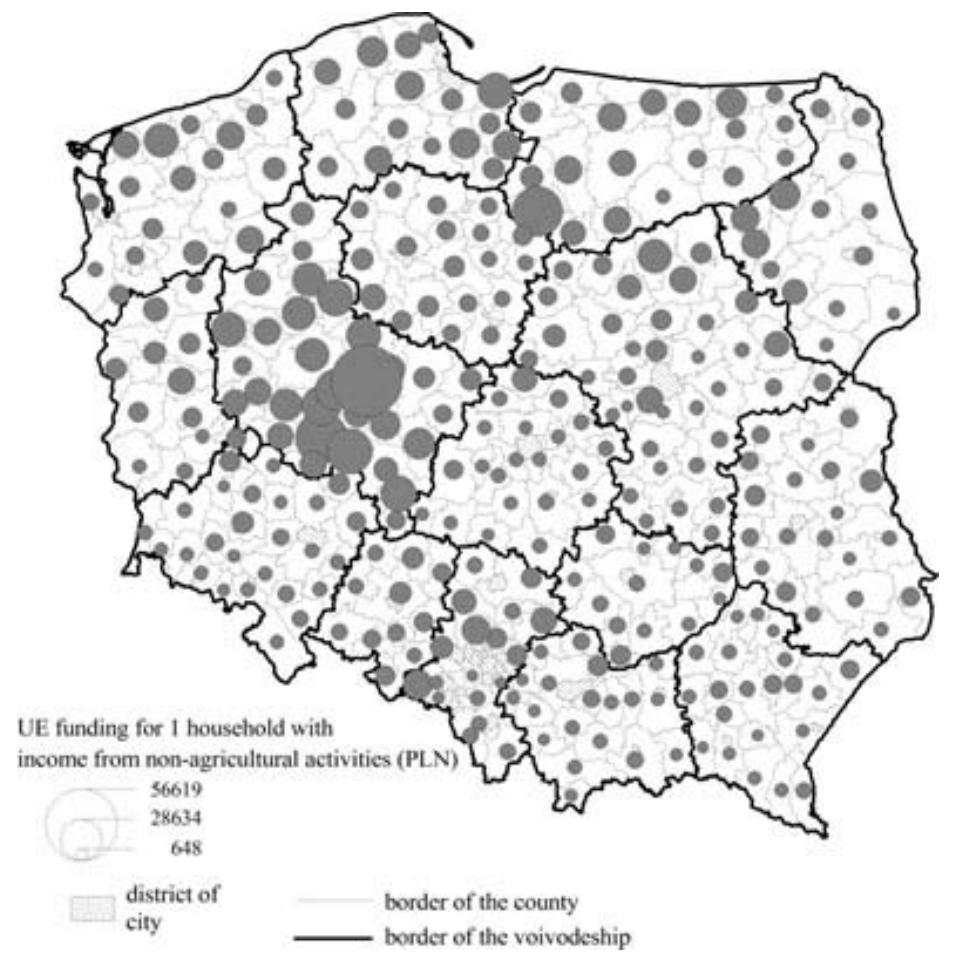

Fig. 9. RDP measures per 1 household farms with income from non-agricultural activities Source: own study. 


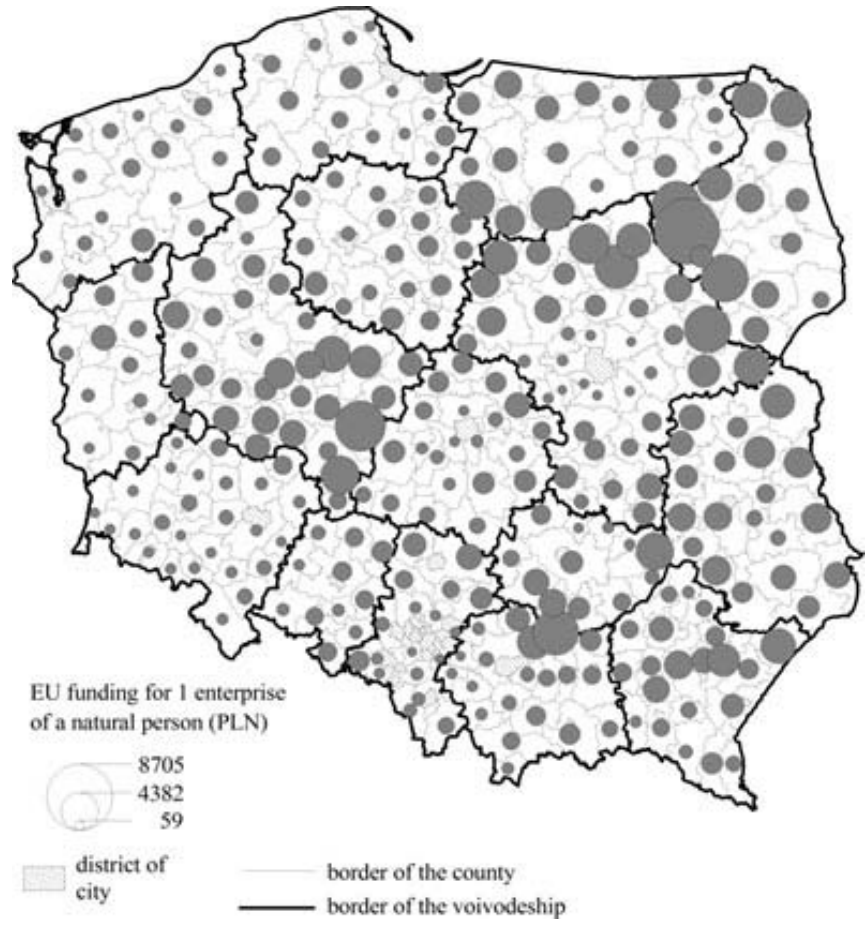

Fig. 10. RDP measures per 1 natural person conducting economic activity Source: own study.

The above indicators were analysed in the form of a standardised composite index which showed the absorption level of the RDP funds. The analysis yielded the following results: the lowest level of absorption - index value below-1.00 - occurred in fifteen

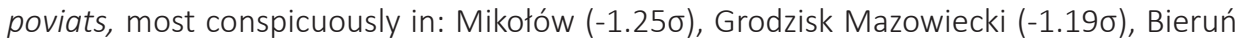
$(-1.12 \sigma)$, and Chrzanów $(-1.12 \sigma)$; the highest level of absorption - index value exceeding $2.00 \sigma-$ featured in thirteen poviats, particularly in: Nowe Miasto Lubawskie (2.75 $\sigma)$,

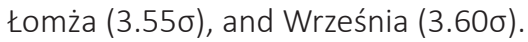

For the final assessment of the RDP funds impact on diversification of economic activity a composite index demonstrating the impact of the RDP on the multi-functional development of rural areas was suggested (standardised score of the indicators of the attractiveness and absorption levels). For the voivodships the index values oscillated be-

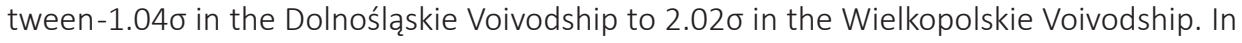
terms of poviats, the values ranged from-1.17 $\sigma$ in the poviat of Mikołów to $4.18 \sigma$ in the poviat of Września (Fig. 11).

The spatial image obtained shows that the most significant impact of the RDP measures on diversification of economic activities occurred in the Wielkopolskie Voivodship and in the northern part of the region of Mazowsze - at the border of the Mazowieckie, Podlaskie and Lubelskie Voivodships - and in the western part of the Warmińsko-Mazurskie Voivodship. A considerably less significant impact of this programme was recorded in the southern Poland, where - apart from a few poviats - the value of the composite index was by far lower than the national average. 


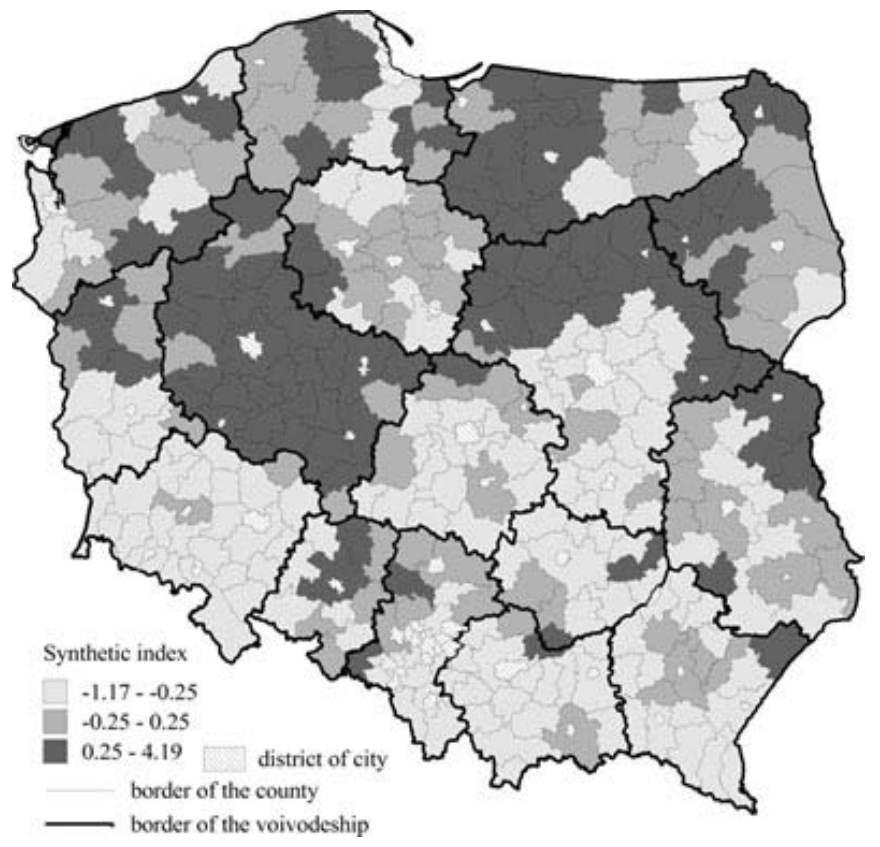

Fig. 11. Synthetic index evaluating the impact of the RDP on diversification of economic activities Source: own study.

Such a pattern indicates the existence of a wide array of factors affecting the level of entrepreneurial activity among rural population. The best example of that can be presented on the basis of the differences between the adjacent voivodships: Wielkopolskie and Kujawsko-Pomorskie. In both regions with relatively similar natural conditions the agricultural sector plays a significant role. However, it is in Wielkopolska where the farmers exhibit high involvement in diversification of their economic activities, whereas in $\mathrm{Ku}$ jawy or in the Land of Dobrzyn farmers with their favourable attitude to maintaining their agricultural activity prevail. It proves that there are several other reasons for farmers' activity, or its lack, in applying for the support instruments under discussion, including for instance the socio-cultural ones (the region of Wielkopolska has 'always' been perceived as an economically-sound and thriving region with a high level of agrarian culture and entrepreneurial flair).

\section{Impact of the European funds on multi-functional development - comments and observations}

The results of the analysis demonstrate significant differences in the impact of the RDP funds designed for diversification of the sources of income earned by rural inhabitants and for subsidising the ventures targeted at non-agricultural economic activity. The elimination of a series of barriers (which had been present in the previously implemented financial programmes covered by European funds) in access to these funds considerably contributed to the financial support which was supposed to stimulate the non-agricultu- 
ral function of the agricultural holdings with a less firm economic footing, to reach agricultural holdings located in areas with favourable natural conditions and a high general level of agrarian development (Rudnicki 2012).

The assessment of the spatial distribution of the index showing the impact of the RDP on diversification of economic activity in rural areas is ambiguous. The ambiguities arise, for example, in the case of a variety of poviats characterised by a high indexation. They are mostly located in touristically popular regions of northern Poland, but they occur in poorly-developed and less-thriving regions of eastern Poland as well. Moreover, they can be found in areas with a well-established agricultural sector (Wielkopolskie Voivodship, part of Opolskie Voivodship). Such a high diversification is due to several factors. These may include e.g.: formal and legal changes in access to the European funds designed for fostering non-agricultural economic activity in rural areas; broad definition of beneficiaries in the RDP (compared to previous programmes), including those from relatively better developed areas and those more involved in provision of services for agriculture and rural inhabitants; socio-cultural changes (other mindset and other attitudes exhibited by rural population); promotion of success stories and popularisation of good practices in the use of the European funds. Nonetheless, as far as the reduction in spatial disproportions in the rural labour market is concerned, the RDP measures contribute to the changes affecting the diversification of sources of income among rural dwellers. The examples of a high activity of beneficiaries featuring poviats with quite dissimilar developmental conditions (natural, social, cultural, economic or arising out of the geographic rent - location) prove the complexity of factors affecting the entrepreneurial attitudes, on the one hand, and substantiate the positive impact of the European funds discussed here, on the other.

Upon juxtaposition of the RDP 2007-2013 with the results of studies related to the previously implemented financial programmes of the EU it can be concluded that there is an increasing emphasis on the funds which are allocated for non-agricultural activities. Inasmuch as in the past the pressure was on activities aiming at the development of rural tourism and agri-tourism, nowadays other forms of service provision are gaining in importance: services in support of agriculture and dedicated for raising the standards of life of rural population. As highlighted by R. Rudnicki (2012), these changes are taking place together with a diminishing role of farmers (seen as EU funds beneficiaries) in the areas with poor agrarian development and unfavourable natural conditions. It is an undesirable phenomenon because in view of their limited potential for income generation from agricultural activity it is these areas, this should prioritize the development of alternative sources of income.

The RDP funds have a positive impact on the diversification of the sources of income and, thus, on the stimulation of the multi-functional development. Nevertheless, some of them were inappropriately invested in terms of diversification into non-agricultural activity. A good case in point may be, for example, a purchase of tractors and agricultural machines which can be used for provision of services to other farmers, yet they remain to be utilised mainly for the purposes of the agricultural sector. At this point, examples cited from the so-called codes of good practices issued by the Agency for Restructuring and Modernisation of Agriculture [ARiMR] for promotional actions are useful illustrations of the problem. Here are some of them: 
[...] farmers decided to set up non-agricultural economic activity and applied for European subsidies. They acquired money from the RDP 2007-2013 Measure 'Diversification into non-agricultural activity' and dedicated it for purchasing a tractor and agricultural machines. So equipped, they could have started providing agricultural services.

Yet the expression: 'could have started' does not mean 'started'; therefore, it can be inferred from the description of the venture that the appropriate allocation of resources - in terms of their purpose - leaves room for some doubts.

Below there is another example of misallocation of funds: this time a farmer was a beneficiary of two RDP measures - 'Modernisation of agricultural holdings' and 'Diversification into non-agricultural activity':

[...he] fitted the pigsty with new equipment and ventilation, and insulated the livestock housing against cold. He upgraded the equipment for preparation of loose feeding stuffs by adding a special set of machines. He also purchased a septic tanker for automatic collection, transportation and disposal of liquid manure and slurry over the field. He had a power generator installed in his agricultural holding. The subsidies covered the costs of new internal access roads and a manoeuvring site. Moreover, he bought a tractor with a frontal gripping truck and scales with the load capacity of up to 60 tons. He also paved $100 \mathrm{~m}^{2}$ of land for these scales.

It cannot be excluded that some of the equipment purchased by that farmer will be used for other purposes than stricte agricultural purposes, but it is quite clear that he was mostly driven by desire to improve the economic potential of his agricultural holding rather than by seeking other sources of income. Inasmuch as ventures like those do not raise any reservations under the measure 'Modernisation of agricultural holdings', it is difficult to find there anything to match the objectives of the measure 'Diversification into non-agricultural activity'.

Naturally, the examples quoted above do not obscure the positive effects of the RDP measures discussed here. However, they point to the irregularities in or ambiguous justification of some ventures (still, it is not only in the case of investment covered by European funds that such irregularities and ambiguities occur). Nevertheless, the fundamental assumptions of Axis 3 of the RDP were delivered to a large extent. It contributed to a reduction in spatial disproportions in the economic development of rural areas in Poland, including, in particular, boosted entrepreneurship in the eastern Poland. The financial European support dedicated to the farmers undertaking additional, non-agricultural activities is an important factor in the multi-functional development of rural areas.

\section{Conclusions}

The support for the development of enterprises in the rural areas following the Polish accession to the European Union resulted in a dynamic growth and economic diversification of rural areas. Thus, the level of multi-functionality of rural areas, which not so long ago were mono-functional (with agriculture being that single function), is raising. Over $90 \%$ of all entrepreneurs who took advantage of external support (from the EU) deem the impact of these funds on the development of their business positive or very positive. Therefore, 
despite the problems recorded in relation to various inconveniences in applying for external funds, in their final judgement entrepreneurs perceive the undoubted benefits of the aid awarded to them (Report..., p. 23).

In the light of a growing global competitiveness reflected in the constant pressure to be cheaper, better or quicker, changes in the agricultural sector are inevitable. Modernisation and enlargement of economically viable agricultural holdings are taking place parallel to a decrease in the total number of agricultural holdings - mostly those with lower economic potential. Thus, the deagrarisation of rural areas, associated with a noticeably diminished role of agriculture in the functioning of rural areas, necessitated the development of rural areas in multiple directions or involving multiple sectors.

The multi-functionality of rural areas and agriculture may be perceived in multitude ways. It is a symptom of changes and progress in human development; it entails simultaneous and compliant existence of various economic, social and environmental functions (Adamowicz 2004). As concluded by Wilkin (2007), it should be strictly identified with the non-market results of agricultural operations which sometimes outweigh the market ones. If that conclusion is transferred onto the ground of the CAP, its aptitude is evident there. It is so because the CAP seeks to change farmers' attitudes through stimulation of and provision of subsidies for their activities by means of the EU funds, even if the grants are not fully justifiable from the economic perspective (the internal agricultural market is highly protected and subsidised). The fact finds it reflection in the measures under the programmes implemented in rural areas. No matter how these programmes are judged, in Poland they undoubtedly accelerated the transformation of rural areas towards multi-functional development.

This paper has been elaborated within the framework of the research project: DEC-2012/07/B/HS4/00364, The impact of the financial instruments of the European Union on the socio-economic development of rural areas in Poland.

\section{References}

Adamowicz M., 2004, Wielofunkcyjność rolnictwa jako podstawa przewartościowania w polityce rolnej, Wieś i Rolnictwo, 4 (1215), pp. 9-30.

Adamowicz M., 2005, Przesłanki rozwoju wielofunkcyjności rolnictwa i zmian we Wspólnej Polityce Rolnej, Zagadnienia Ekonomiki Rolnej, cz. 1 (302), Warszawa, pp. 17-32;

Bański J., 2003, Pozarolniczy rozwój gospodarczy na obszarach wiejskich w Polsce, Przegląd Geograficzny, 75, 2, pp. 385-401.

Bański J., 2004, Możliwości rozwoju alternatywnych źródeł dochodu na obszarach wiejskich, Studia Obszarów Wiejskich, 5, pp. 9-22.

Biczkowski M., 2008, Absorpcja funduszy unijnych szansq rozwoju obszarów wiejskich, [in:] D. IInicki, K. Janc (eds.), Przekształcenia regionalnych struktur funkcjonalno-przestrzennych - Europa bez granic - nowe wyzwania, Rozprawy Naukowe Instytutu Geografii i Rozwoju Regionalnego Uniwersytetu Wrocławskiego 3, Wyd. Uniwersytetu Wrocławskiego, Wrocław, pp. 277-286.

Biczkowski M., 2010, Pozarolnicza działalność gospodarcza użytkowników indywidualnych gospodarstw rolnych w województwie kujawsko-pomorskim, Acta Scientiarum Polonorum, Oeconomia, 9 (3), SGGW, Warszawa. 
Bułkowska M., Chmurzyńska K., 2007, Wyniki realizacji PROW i SPO Rolnictwo w latach 20042006, [in:] Ekonomiczne i społeczne uwarunkowania rozwoju polskiej gospodarki żywnościowej po wstapieniu Polski do Unii Europejskiej, Seria Program Wieloletni 2005-2009, 65, 7, IERiGż-PIB, Warszawa.

Creation of the concept of systemic support of entrepreneurship in rural areas within the project 'Growth of entrepreneurship in rural areas - diagnosis, directions of and recommendations for rural development policy'. Strategic report, Institute of Geography and Spatial Organization Polish Academy of Sciences (IGSO PAS), Foundation for the Development of Polish Agriculture, Warsaw 12 May 2014.

Dietl J., Gregor B., 1979, Funkcje obszarów wiejskich oraz ich wpływ na obsługę handlowq, Biuletyn KPZK PAN, 101, pp. 79-95.

Durand G., Huylenbroeck G., 2003, Multifunctionality and rural development; a general framework [in:] Multifunctional Agriculture. A New Paradigm for Eiropean Agriculture and Rural Development, Ashgate.

Głaz M., 2008, Działalność gospodarcza na obszarach wiejskich w strefie oddziaływania Wrocławia, [in:] J. Słodczyk, M. Śmigielska (eds.), Współczesne kierunki i wymiary procesów urbanizacji, Uniwersytet Opolski, s. 338-347.

Głaz M., 2010, Wielofunkcyjność wsi w strefie podmiejskiej Wrocławia, maszynopis pracy doktorskiej, Uniwesytet Wrocławski, Instytut Geografii i Rozwoju Regionalnego, Wrocław.

Hasiński W., Głaz M., Kemona S., 2004, Agroturystyka jako alternatywne źródło dochodów gospodarstw rolnych na Dolnym Ślq̨sku, Studia Obszarów Wiejskich, 5, pp. 137-150.

Hunek T., 1990, Wielofunkcyjność rolniczego gospodarstwa domowego w strategii rozwoju wsi i rolnictwa, Wieś i Rolnictwo, 3.

Kamińska W., 2004, Przedsiębiorczość osób fizycznych na obszarach wiejskich w 2003 roku, Studia Obszarów Wiejskich, 5, pp. 35-45.

Kłodziński M., 1995, Uwarunkowania wielofunkcyjnego rozwoju gminy, [in:] L. Klank (ed.), Wieś i rolnictwo w okresie transformacji systemowej, IRWiR, Warszawa.

Kłodziński M., 1996, Wielofunkcyjny rozwój terenów wiejskich w Polsce i krajach Unii Europejskiej, SGGW, Warszawa.

Kłodziński M., 2001, Problemy przekształceń obszarów wiejskich w kierunku wielofunkcyjności, [in:] I. Bukraba-Rylska, A. Rosner (eds.), Wieś i rolnictwo na przełomie wieków, IRWiR PAN, Warszawa, pp. 7-23.

Kłodziński M., 2004, Ekonomiczne i społeczne uwarunkowania i możliwości wielofunkcyjnego rozwoju wsi po integracji Polski z UE, Wieś i Rolnictwo, 2 (123), pp.108-118

Kłodziński M., 2006, Aktywizacja społeczno-gospodarcza gmin wiejskich i małych miast, Problemy Rozwoju Wsi i Rolnictwa, IRWiR PAN, Warszawa.

Kołodziejczyk D., 2002, Uwarunkowania społeczno-gospodarcze lokalnego rozwoju gospodarczego, Studia i Monografie, 113, IERigż, Warszawa.

Kołodziejczyk D., 2004, Pozarolnicza działalność gospodarcza w indywidualnych gospodarstwach rolnych w skali gmin, Studia Obszarów Wiejskich, 5, pp. 23-34.

Kostrowicki J., 1976, Obszary wiejskie jako przestrzeń wielofunkcyjna. Zagadnienia badawcze i planistyczne, Przegląd Geograficzny, 48, 4, pp. 601-611.

Kropsz I., Kutkowska B., 2008, Stan przedsiębiorczości na obszarach wiejskich Dolnego Ślq̨ska, Wieś i Rolnictwo, 1 (138), pp. 88-103.

Pałka E. (red.), 2004, Pozarolnicza działalność gospodarcza na obszarach wiejskich, Studia Obszarów Wiejskich, 5, IGiPZ PAN, PTG, Warszawa. 
Program Rozwoju Obszarów Wiejskich na lata 2007-2013, 2007, Ministerstwo Rolnictwa i Rozwoju Wsi i Rolnictwa, Warszawa.

Racine J.B., Reymond H., 1977, Analiza ilościowa w geografii, PWN, Warszawa.

Rudnicki R., Biczkowski M., 2004, Zróżnicowanie przestrzenne i uwarunkowania pozarolniczej dziatalności gospodarstw rolnych w województwie kujawsko-pomorskim, Studia Obszarów Wiejskich, 5, pp. 103-122.

Rudnicki R., 2012, Instrumenty Wspólnej Polityki Rolnej ukierunkowane na różnicowanie działalności gospodarczej w rolnictwie jako czynnik aktywizacji wiejskiego rynku pracy w Polsce w latach 2003-2010, [in:] W. Kamińska, K. Heffner (eds.), Wiejskie rynki pracy - zasoby, aktywizacja, nowe struktury, Studia KPZK PAN, CXLV, Warszawa, pp. 179-208.

SAPARD, Program operacyjny dla Polski, 2002, Ministerstwo Rolnictwa i Rozwoju Wsi, Warszawa.

Sektorowy Program Operacyjny „Restrukturyzacja i modernizacja sektora żywnościowego oraz rozwój obszarów wiejskich”, 2004, Narodowy Plan Rozwoju na lata 2004-2006, Ministerstwo Rolnictwa i Rozwoju Wsi, Warszawa.

Skawińska E., 1994, Wielofunkcyjny rozwój obszarów wiejskich w regionie toruńskim, Wydawnictwo UMK, Toruń.

Spychalski G., 2005, Mezoekonomiczne aspekty kształtowania rozwoju obszarów wiejskich, IRWiR PAN, Warszawa.

Stola W., 1982, Klasyfikacja funkcjonalna obszarów wiejskich Polski, Przegląd Geograficzny, 54, 4, pp. 427-451.

Stola W., 1987, Klasyfikacja funkcjonalna obszarów wiejskich Polski. Próba metodyczna, IGiPZ PAN, Warszawa.

Stola W., 1993, Struktura przestrzenna i klasyfikacja funkcjonalna obszarów wiejskich Polski, Dokumentacja Geograficzna, 3, IGiPZ PAN, Warszawa.

The European Charter for rural areas, 1996, Wieś i Państwo 2/3, pp. 213-234.

The Future of Rural Society, 1988, Bulletinn of the European Communities, supplement 4/88, Commission Communication transmitted to the Counsil and to the European Parliament on 29 July 1988.

Wilkin J., 2007, Uwarunkowania rozwoju polskiego rolnictwa w kontekście europejskim i globalnym. Implikacje teoretyczne i praktyczne - Paper prepared for the VIII Congress of Polish Economists, 29-30.11.2007.

Wójcik M., 2004, Rozwój pozarolniczej działalności gospodarczej w wybranych gminach wiejskich aglomeracji tódzkiej, Studia Obszarów Wiejskich, 5, pp. 123-136.

Zarębski M., 2002, Bariery i możliwości wielofunkcyjnego rozwoju obszarów wiejskich (na przykładzie regionu konińskiego), UMK, Toruń. 